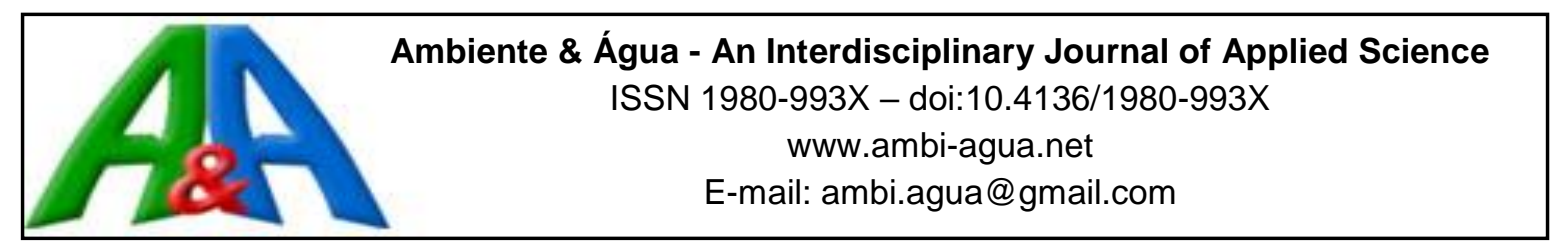

\title{
Behavioral changes in female Swiss mice exposed to tannery effluents
}

\author{
doi:10.4136/ambi-agua.1852
}

Received: 29 Jan. 2016; Accepted: 07 May 2016

\author{
Sabrina Ferreira de Almeida; Letícia Martins Rabelo; \\ Joyce Moreira de Souza; Raíssa de Oliveira Ferreira; \\ Abraão Tiago Batista Guimarães; Caio César Oliveira Pereira; \\ Aline Sueli de Lima Rodrigues; \\ Guilherme Malafaia* \\ Instituto Federal Goiano (IF Goiano), Urutaí, GO, Brasil \\ Departamento de Ciências Biológicas \\ "Corresponding author: e-mail: guilhermeifgoiano@gmail.com, \\ saualmeida@hotmail.com, lee.martins_@hotmail.com, \\ joycemsabio@gmail.com, raissaferreira374@gmail.com, \\ abraaotbgbio@gmail.com, caiocesar.op@ hotmail.com, \\ alineifgoiano@gmail.com
}

\begin{abstract}
Among the anthropic activities generating potentially toxic residues are those involved with bovine hide processing (tannery industries). However, knowledge is scant regarding the damage caused to the health of various organisms by tannery waste and studies are rare, especially in mammalian experimental models. This study therefore aimed to evaluate the physical and behavioral effects of the exposure of female Swiss mice to tannery effluent. To accomplish this, for a period of 15 days the animals were fed tannery effluent diluted with water in the following concentrations: $0 \%$ (control group, received only potable water), 5\% and $10 \%$. The body mass of the animals was evaluated at the beginning and end of the experiment, as well as the daily consumption of water and food. After 15 days of exposure to the effluent, the animals were submitted to the elevated plus maze (predictive of anxiety) and the forced swim test (predictive of depression). The treatments did not affect the animals' body mass, either in eating behavior or in consumption of water. However, it was found that the animals that ingested tannery effluent concentrations of 5\% and $10 \%$ exhibited an anxiolytic (lower level of anxiety, greater percentage of time in the open arms, longer time and frequency in the diving behavior, less time of lurks and less frequency of freezing) and an antidepressant effect (more time in climbing behavior and less time of immobility) when compared to the control group. It was concluded that the exposure of female Swiss mice to tannery effluents (5\% and $10 \%$ diluted with water) causes behavioral changes, possibly related to the neurotoxicity of this waste, without causing physical changes in the animals.
\end{abstract}

Keywords: agricultural residues, animal model, anxiety, depression, toxicity, xenobiotics.

\section{Alterações comportamentais em fêmeas de camundongos Swiss expostas à efluente de curtume}

\section{RESUMO}

Uma das atividades antrópicas geradoras de resíduos potencialmente tóxicos refere-se 
àquelas ligadas ao processamento do couro bovino (indústrias curtumeiras). Embora se saiba que essas indústrias ao descartarem incorretamente seus resíduos líquidos no ambiente contribuem para o aparecimento de prejuízos na saúde de diferentes organismos, raros são os estudos que investigaram os efeitos desses resíduos em modelos experimentais mamíferos. Logo, o presente estudo objetivou avaliar os efeitos físicos e neurocomportamentais da exposição de fêmeas de camundongos Swiss a efluente de curtume. Para isso, os animais receberam pela via oral, por um período de 15 dias, concentrações de $5 \%$ e $10 \%$ de efluente de curtume, diluído em água. O grupo controle recebeu apenas água potável. A massa corpórea dos animais foi avaliada no início e ao final do experimento. Já o consumo de água e ração foi aferido diariamente. Após 15 dias de exposição, os animais foram submetidos ao teste do labirinto em cruz elevado (preditivo de ansiedade) e ao teste do nado forçado (preditivo de depressão). Os resultados demonstram que os tratamentos não provocaram alterações na massa corpórea dos animais, tampouco no comportamento alimentar e no consumo de água. Por outro lado, observou-se nos animais dos grupos 5\% e $10 \%$ de efluente de curtume efeito ansiolítico dos tratamentos, assim como efeito antidepressivo, quando comparados aos animais do grupo controle. Logo, conclui-se que em fêmeas de camundongos Swiss a exposição a concentrações de $5 \%$ e $10 \%$ de efluente de curtume diluído em água, embora não tenha causado alterações físicas nos animais, pode causar alterações neurocomportamentais, possivelmente relacionadas à neurotoxicidade desses resíduos.

Palavras-chave: ansiedade, depressão, modelo animal, resíduos agroindustriais, toxicidade, xenobióticos.

\section{INTRODUCTION}

One of the wastes produced on a large scale, which is often discarded directly into the environment without prior treatment and is considered a public health problem in countries like Brazil, China, Pakistan and India, is tannery effluent (Prabakaran et al., 2007). Such residues, as discussed by Gödecke et al. (2012), are produced in different stages of bovine-hide processing that require various mechanical and chemical treatment processes, which give the effluent a high potential for transmitting toxicity to the environment and organisms.

Recent studies in humans have shown a relationship between exposure to tannery effluent and the onset of otorhinolaryngological (ENT organs), dermatological, ophthalmic, respiratory, reproductive, and neuronal problems (Cuberos et al., 2009; Greene et al., 2012; Rumin et al., 2013; Chandrasekaran et al., 2014). Several experiments have already reported the effects of tannery effluents in inducing teratogenicity in sea urchin species, reducing the growth of microalgae and in a variety of toxic effects on micro crustaceans (Oral et al., 2005). Other studies have also shown the harmful effects of tannery effluents on fish, plants and bacteria (Tagliari et al., 2004; Matsumoto et al., 2006; Mitteregger Jr. et al., 2007; Tigini et al., 2011; Taju et al., 2012). However, studies of the effects of these pollutants on more complex organisms, such as mammals, are still incipient.

Only a few authors have evaluated the effect of tannery effluents on mammals, among which are Kumar et al. (2008), Siqueira et al. (2011), Moysés et al. (2014), Silva et al. (2015), Lemos et al. (2015), Ferreira et al. (2015), Souza et al. (2016) and Rabelo et al. (2016). In the pioneering study by Kumar et al. (2008), chronically exposing male Wistar rats to tannery effluent, the authors observed a mass increase of all of the androgen-dependent organs evaluated, such as the prostate and seminal vesicle, and found deformations in the seminiferous tubules with testicular hyperplasia signals.

Siqueira et al. (2011) demonstrated that male Swiss mice given untreated $1 \%$ tannery effluent diluted with water for a period of only 15 days exhibited anxiety-like behavior. 
However, Moysés et al. (2014), studying the neurotoxicity and hepatotoxicity induced by the chronic exposure of male Wistar rats to tannery effluents, did not observe any change in the variables investigated.

Recently, Rabelo et al. (2016) demonstrated that exposure to tannery effluent caused memory deficit in Swiss mice in a similar way for both sexes, reinforcing previous findings that these pollutants affect the central nervous system. In Souza et al. (2016), moderate hydropic degeneration was detected in animals (C57B1/6J mice) exposed to tannery effluents, mainly in the periportal space. A large number of necrotic hepatocytes were detected, especially in animals exposed to higher tannery effluent concentrations. Further, the largest number of hepatocytes with karyomegaly was observed in animals exposed to the highest effluent concentrations.

On the other hand, the studies by Silva et al. (2015), Lemos et al. (2015) and Ferreira et al. (2015) evaluated lethal doses of tannery effluents diluted with water at different concentrations, using different sexes and strains of mice. While considered pioneering works related to the evaluation of acute toxicity and determination of lethal doses of tannery effluent in mice, these studies did not investigate the neurobehavioral effects in the animals, linked to neuropsychiatric disorders such as anxiety and depression.

Thus, there is a clear gap regarding knowledge of the effects of exposure to tannery effluents in mammalian experimental models, which makes it difficult to extrapolate or approximate the possible effects of exposure on human beings. Besides the scarcity of studies of this kind, the few works related to tannery effluent intake focused on male mammals (Siqueira et al., 2011; Moysés et al., 2014), requiring that further study be done regarding the possible effects on female animals. This study therefore aimed to evaluate behavioral changes predictive of anxiety and depression caused by tannery effluent intake by female Swiss mice.

\section{MATERIALS AND METHODS}

\subsection{Animals and experimental groups}

This study used 35 female Swiss mice (6.5 months old) from matrices of the Animal Facility of the Biological Research Laboratory at Federal Institute of Goiás (IF Goiano) Câmpus Urutaí (Urutaí, GO, Brazil). All of the animals were kept under sanitary conditions at a conventional animal facility, under temperature $\left(22\right.$ to $\left.24^{\circ} \mathrm{C}\right)$ and light control $(12 \mathrm{~h}$ light cycle). The standard diet for rodents (Nuvilab CR 1) and water was offered ad libitum. The procedures adopted in this study were approved by the Ethics Committee on Animal Use (CEUA) of the Instituto Federal Goiano (IF Goiano) - Campus Urutaí (Urutaí, GO, Brazil) (protocol n. 17/2014).

The animals were divided into three experimental groups, which received tannery effluent diluted with drinking water at the following concentrations: 0\% (control group), which received only potable water; 5\% tannery effluent (concentration defined based on Moysés et al. (2014)) and 10\% tannery effluent (twice the maximum dosage defined by Moysés et al. (2014)). Furthermore, concentrations of 5\% and $10 \%$ of tannery effluent match with $1 / 12$ and $1 / 6$ of the median lethal dose $\left(\mathrm{LD}_{50}\right)$ given to female Swiss mice (Ferreira et al., 2015).

\subsection{Management of tannery effluent}

Each animal orally received (by gavage) a volume of $1 \mathrm{ml}$ of liquid (water - control group - or tannery effluents diluted with water $-5 \%$ and $10 \%$ groups) twice a day, , totaling $2 \mathrm{ml}$ of liquid daily, for a period of 15 days [exposure period based on the study of Siqueira et al. (2011)]. The management of liquids by gavage was chosen in order to allow control of the amount of intake. 


\subsection{Tannery effluent and water used}

The tannery effluent used in this study was the wet-blue type, obtained from a tannery industry located in Inhumas, GO, Brazil. The chemical characterization of the tannery effluent used indicates the presence of high concentrations of heavy metals compared to the drinking water used for diluting the waste (Table 1).

Table 1. Physicochemical and chemical characterization of the untreated tannery effluent used in the present study ${ }^{\#}$.

\begin{tabular}{|c|c|c|}
\hline Parameters & Potable water & Untreated effluent \\
\hline $\mathrm{pH}$ at $25^{\circ} \mathrm{C}(\mathrm{UpH})$ & 7.20 & 4.05 \\
\hline Total solids (mg L $\left.{ }^{-1}\right)$ & 80.00 & $37,380.00$ \\
\hline Total sodium $\left(\mathrm{mg} \mathrm{L}^{-1}\right)$ & 5.25 & $9,690.00$ \\
\hline Total zinc $\left(\mathrm{mg} \mathrm{L}^{-1}\right)$ & 0.03 & 0.30 \\
\hline Calcium $\left(\mathrm{mg} \mathrm{L}^{-1}\right)$ & 4.00 & 601.20 \\
\hline Lead $\left(\mathrm{mg} \mathrm{L}^{-1}\right)$ & $<0.01$ & 0.32 \\
\hline Arsenic $\left(\mathrm{mg} \mathrm{L}^{-1}\right)$ & $<0.01$ & $<0.01$ \\
\hline Magnesium $\left(\mathrm{mg} \mathrm{L}^{-1}\right)$ & 2.43 & 364.80 \\
\hline Chrome (mg L ${ }^{-1}$ ) & $<0.05$ & 859.00 \\
\hline Cadmium (mg L $\left.{ }^{-1}\right)$ & $<0.001$ & 0.095 \\
\hline Nickel $\left(\mathrm{mg} \mathrm{L}^{-1}\right)$ & $<0.01$ & 0.55 \\
\hline
\end{tabular}

\subsection{Feed and water intake and behavioral analysis}

Consumption of water and food by the animals was measured daily. Calculations of feed and water intake were obtained by the daily subtraction of the amounts refused from the amounts offered on the subsequent day.

Tests predictive of anxiety and depression were performed on the animals in order to evaluate the possible behavioral effects of tannery effluent intake diluted with water, as itemized below.

\subsubsection{Elevated plus maze test (EPM)}

On the 16th experimental day, the EPM test was performed according to the procedures proposed by Walf and Frye (2007) and Komada et al. (2008). The animals' anxiety index was calculated according to Estrela et al. (2015): Anxiety Index $=1-[([$ Open arm time/Test duration $]+[$ Open arms entries/Total number of entries])/2]. Furthermore, the percentage of time spent in the open and closed arms was evaluated, as this is regarded as a primary parameter of the EPM according to Walf and Frye (2007). Complementary ethological parameters were also evaluated, to include: stretched-attend postures (exploratory postures in which the body is stretched forward then back to its original position without any locomotion forward), head-dippings [exploratory movements performed in the open arm when the mouse put its head and shoulders down towards the EPM floor level, as Garavelho (2005)], selfcleaning (sequence of oriented movements to clean the head and body) and freezing [operationally defined as the total absence of body and vibrissae movement, except those 
necessary for breathing for at least 6 seconds, according to Reimer et al. (2015)].

All test sessions were recorded by a video camera suspended $30 \mathrm{~cm}$ above the EPM. The behavioral parameters in the EPM were evaluated with the PlusMZ software. Two trained observers reviewed the video; each video was analyzed three times, yielding an inter- and intra-observer agreement greater than $85 \%$.

\subsubsection{Forced swim test}

On the 17th experimental day the forced swim test was conducted, which consisted of maintaining each mouse individually within a cylindrical tank (height $39 \mathrm{~cm}$, depth $20 \mathrm{~cm}$ and diameter $20 \mathrm{~cm}$ ) containing water at $25{ }^{\circ} \mathrm{C}$ for 6 minutes. After the test, the mice were removed from the water and placed in a box with a paper towel and dried without human interference, before being returned to their cages.

All test sessions were videotaped with a video camera located $30 \mathrm{~cm}$ above the tank to allow further evaluation of the time spend in immobility, swimming and climbing behavior, according Can et al. (2012) and Costa et al. (2013). These parameters were recorded and summarized in either one block of 6 min (i.e., the total time of the test), or in one block of 4 min (i.e., the last 4 min of the test) or in the remaining block of 2 min (the first 2 min of the test), as proposed by Costa et al. (2013). Similar to the EPM analysis, two trained observers reviewed the video, and each video was analyzed three times, yielding an inter- and intraobserver agreement higher than $85 \%$.

\subsection{Assessments carried out after the behavioral tests}

\subsubsection{Determination of the phases of the estrous cycle in female mice}

Immediately following the completion of each behavioral test, the estrous cycle of female mice was assessed by vaginal cytology, according to the methodology described by Byers et al. (2012). Since the phase of the estrous cycle in female mice directly influences the behavior of the animals and the results of neurobehavioral tests (Goldman et al., 2007), only the results of females that were in dioestrus were considered for analysis.

Although a total of 35 female Swiss mice were used in this study, each experimental group was composed of at least 6 animals. As the behavioral tests were performed on different days (the 16th and 17th experimental day) and considering that the entire estrous cycle in mice usually lasts 4-5 days, the behavioral parameters quantified for each test were from different females who presented the dioestrus phase on the test day. The same female was seen in more than one behavioral test only in some cases, as the dioestrus phase is the longest stage of the estrous cycle in mice and may last more than $48 \mathrm{~h}$ (Byers et al., 2012).

\subsubsection{Physical evaluation, euthanasia and histological evaluations}

On the 17th experimental day, after the completion of the behavioral tests, the animals were weighed and then euthanized by decapitation to collect fragments of the esophagus and stomach. The purpose of this step was to assess whether the gavage procedure caused macroscopic or histological changes in those organs that could interfere with behavioral outcomes. Moreover, this step evaluated whether treatment with tannery effluent caused histological changes in the structure of these organs, considering the direct contact of these organs with the content of the liquid administered to the animals. After collecting these organs, fragments thereof were subjected to histological preparation, as in Luna et al. (1968) and Behmer et al. (1976). Images of the tissue fragments were taken on histological slides using the TSView image-analysis system, Version 7.1. It is emphasized that all slides of the experimental groups were blinded and then mixed for randomization. All histological analysis was performed by the same observer, using microscope objective lens 40x, 100x and 400x. 


\subsection{Statistical analysis}

The data were first analyzed for residual normality by the Shapiro-Wilk test and for homoscedasticity by the Bartlett's test. Then the data regarding tangible mass, feed and water intake, and behavioral parameters were submitted to one-way analysis of variance (one-way ANOVA) by Tukey's post-test at 5\% probability, using ASSISTAT software, Version 7.7 beta (distributed for free).

\section{RESULTS AND DISCUSSION}

There were no differences in the body mass of animals between the experimental groups (Figure 1A). Moreover, no changes were observed in drinking water or feed intake by the animals of the experimental groups (Figure 1B and 1C), suggesting that the treatments did not alter the feeding behavior of the evaluated animals, which may explain the lack of differences between the animals' corporeal masses at the end of the experiment.

While existing studies regarding tannery-effluent intake in mammalian models (Siqueira et al., 2011; Moysés et al., 2014, Lemos et al., 2015) had not estimated the physical parameters of the animals, weight change is one of most-used parameters in toxicological evaluations to indicate the appearance, often early, of the toxicity of a particular substance in an animal organism (Pires Júnior et al., 2012).

Regarding the histological analysis, there were no histopathological changes in the animals' esophagi (Figure 2) and stomach (Figure 3), demonstrating that the gavage procedure or the contact with liquids, especially with the treatments of $5 \%$ and $10 \%$ tannery effluent, caused no damage to these organs.

Regarding the behavioral tests, when assessed in the EPM, the animals that received water containing $5 \%$ and $10 \%$ tannery effluent showed a lower rate of anxiety, a higher percentage of entries into the open arms and a lower percentage of time spent in the closed arms than did the control group (Figure 4A).

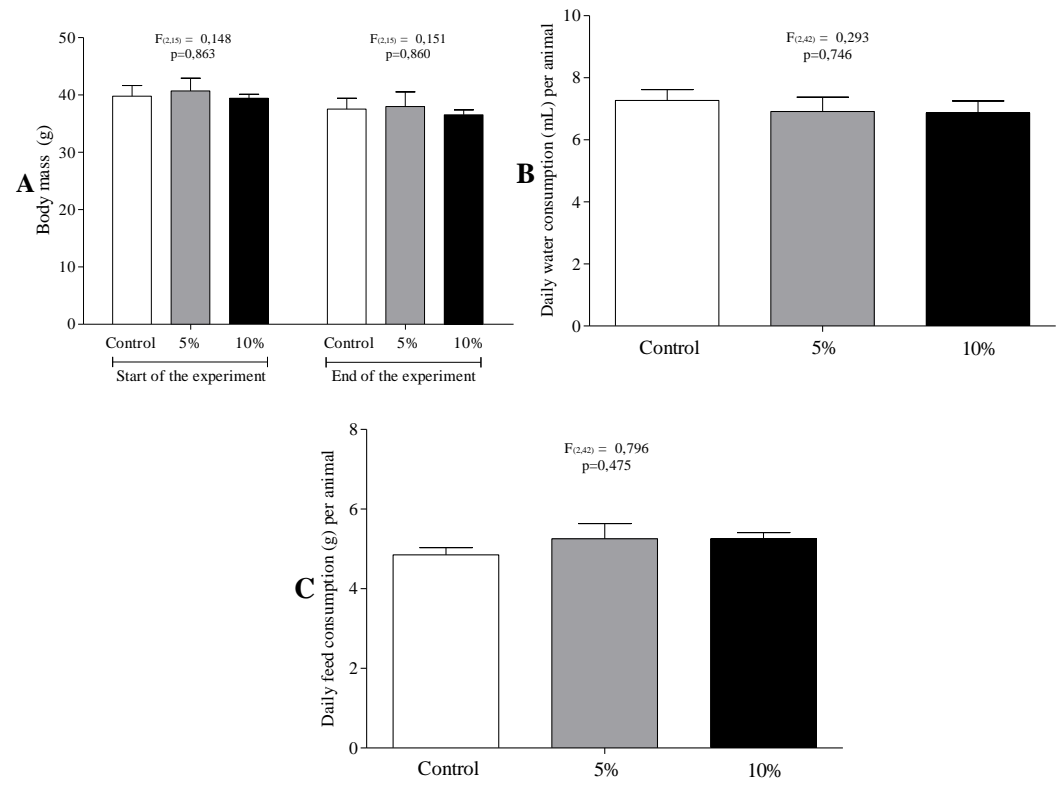

Figure 1. (A) Corporeal mass, (B) water consumption $(\mathrm{mL})$ and $(\mathrm{C})$ feed $(\mathrm{g})$ of female Swiss mice (in dioestrus phase) exposed or not to the tannery effluent intake diluted with water. The data were submitted to simple analysis of variance (one-way ANOVA), at 5\% probability. The bars indicate the mean \pm standard deviation. Control group $(n=6), 5 \%$ of tannery effluent group $(n=6)$ and $10 \%$ of tannery effluent $(n=6)$ group. 
As for ethological parameters evaluated in the EPM, these corroborate the primary behaviors observed in that test, since the animals who ate tannery effluent exhibited more time and frequency of diving behavior and shorter lurking, as well as less frequent freezing behavior (Figure 4B and 4C), results consistent with an anxiolytic effect of the treatments. Regarding the diving behavior, it is inversely associated with anxiety, as discussed by Anseloni and Brandão (1997), which is consistent with the instant study, which found anxiolytic behavior in animals exposed to tannery effluent intake. Regarding lurking behavior, it may be defined as a risk-assessment behavior, which promotes information, confirmation and identification of danger (Espejo, 1997). Therefore, a decrease in the time and frequency of this behavior, as observed in the instant study (Figure 4A and 4B), suggests a decrease animals' anxiety over the situation, in which they are exposed in the EPM test and are less fearful of remaining in the open area of the apparatus.
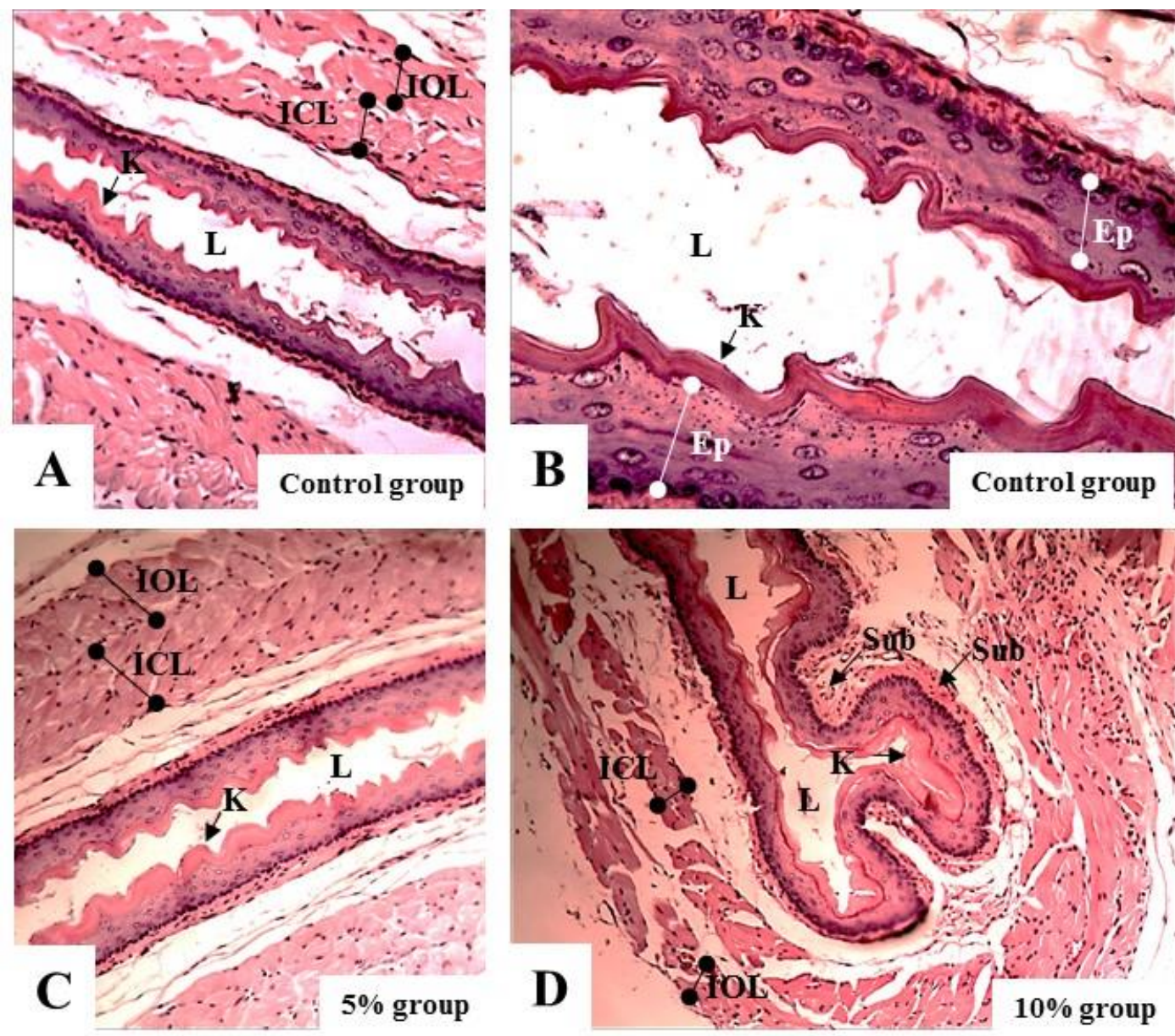

Figure 2. Representative photomicrographs of different regions of the esophagus (A-D) in longitudinal sections, of female Swiss mice (in the dioestrus phase) exposed or not to tannery-effluent intake diluted with water. L: lumen; Ep: mucosal epithelium; $(\mathrm{K})$ : keratin layer; (ICL): inner circular layer of smooth muscle; (IOL): internal outer layer of smooth muscle; Sub: submucosa (formed of dense connective tissue). A-C: 10x magnification. B: 40x magnification. H\&E staining.

On the other hand, in a new environment, or in a potentially dangerous or threatening situation, mice tend to be quiet or still, with tense muscles, and are alert and ready for quick and vigorous action. This defense reaction is called "freezing". Alternating with immobility, the animal can perform careful exploration of the environment, thus making assessing risk. Therefore, a decrease in the frequency of this risk-assessment behavior, as seen in this study 
(Figure 4C), is consistent with an anxiolytic behavior, as discussed in other studies (Pietropaolo et al., 2014).
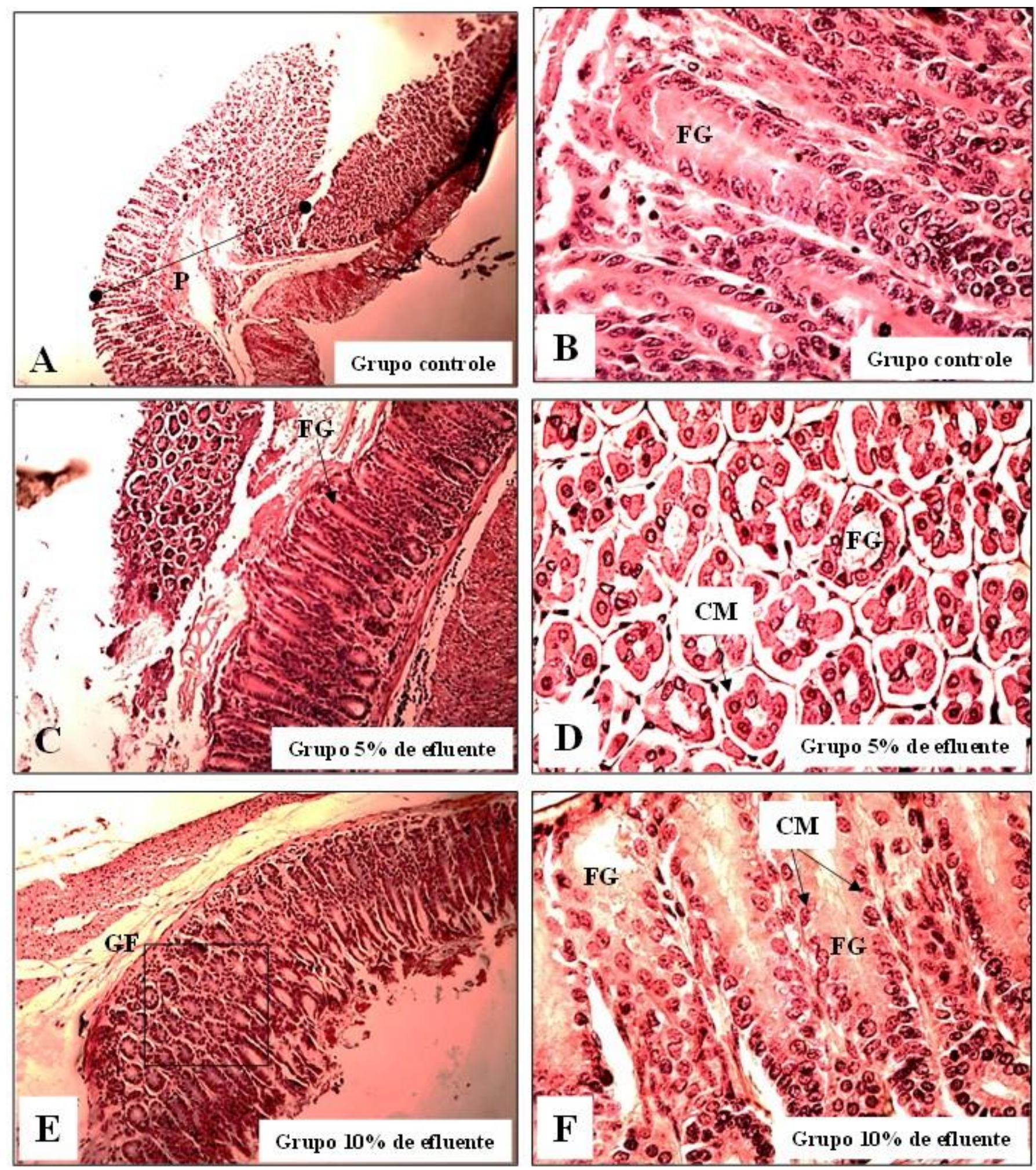

Figure 3. Representative photomicrographs of the fundus of the stomach (A-F) of female Swiss mice (in the dioestrus phase) exposed or not to tannery-effluent intake diluted with water (P): preach; (GP): gastric pit; (FG): fundic glands; (MC): mucosal cells. A, C and E: 10x magnification. B, D and F: 40x magnification. H\&E staining. 

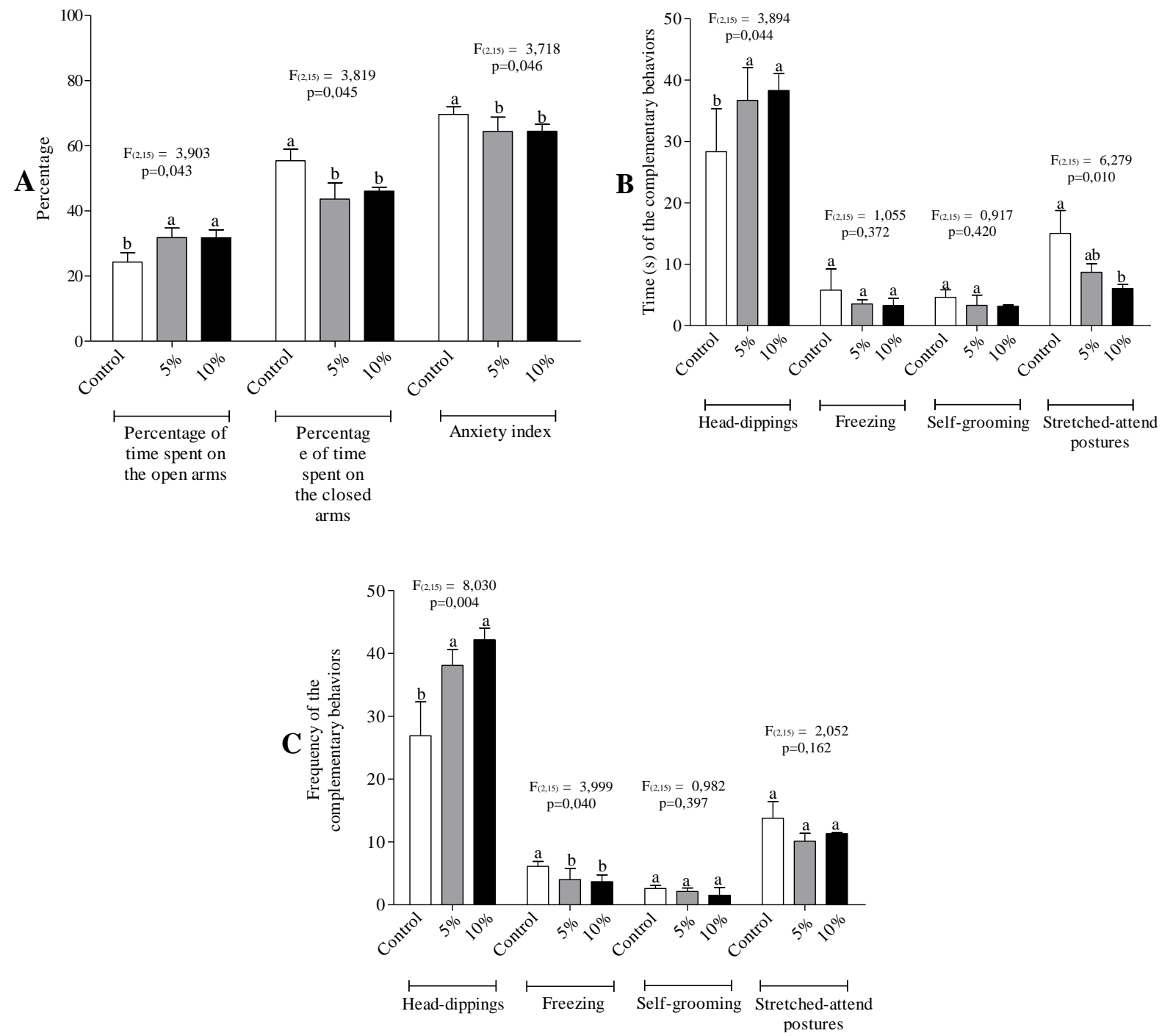

Figure 4. (A) Primary parameters and anxiety index in the EPM test, (B) time and (C) frequency of complementary behavior exhibited by female Swiss mice (in dioestrus phase) exposed or not to tannery effluent diluted with water in the EPM test. Different letters indicate significant differences among the experimental groups. All data were submitted to analysis of variance (one-way ANOVA) with Tukey's post-test at 5\% probability. Control group $(\mathrm{n}=6), 5 \%$ tannery effluent group $(n=6)$ and $10 \%$ tannery effluent group $(n=6)$. Different letters indicate significant differences among the experimental groups.

Surprisingly, the results of this study in the EPM test differ from those shown by Siqueira et al. (2011), which gave three-month old male Swiss mice tannery effluent at a concentration of $1 \%$, and found anxiogenic behavior in the animals. These data, together with the results of this study, suggest that the response of different genders of the Swiss mice strain exposed to tannery effluent appears to be different, although it is important to consider that the chemical composition of the effluent used in the studies may not be similar. In the study by Siqueira et al. (2011), the authors did not provide information on the chemical composition of the effluent used, noting only that the effluent used contained high organic and inorganic loads and high concentrations of chlorides and chromium salts. This fact makes it difficult to assess the factors related to the effluents used, which might explain the differences between the studies and allow us to infer that the chemical composition of the effluents may be the cause the different responses of the organisms to exposure.

Especially with regard to gender, according to Waxman and Holloway (2009), sex 
differences in pharmacokinetics and pharmacodynamics characterize many drugs and contribute to individual differences in toxicity. Sex-based differences in drug metabolism are the primary cause of sex-dependent pharmacokinetics and reflect underlying sex differences in the expression of hepatic enzymes active in the metabolism of drugs, steroids, fatty acids and environmental chemicals, including cytochromes P450 (P450s), sulfotransferases, glutathione transferases, and UDP-glucuronosyltransferases. Studies in rat- and mouse-liver models have identified more than 1000 genes whose expression is sex-dependent; together, these genes impart substantial sexual dimorphism to liver metabolic function, pathophysiology and neurobehavioral. Thus, the differences between the present study and the study of Siqueira et al. (2011) may also be explained by the sex difference of the animals evaluated.

Moreover, this study differs from the study by Moysés et al. (2014), who found that three-month old male Wistar rats exposed to different concentrations of untreated tannery effluent $(0.1 \%, 1 \%$ and $5 \%)$, also diluted with water, exhibited no changes in any of the behavioral parameters evaluated during the EPM test. Besides the differences between the types of effluents used in the instant study and in the study by Moysés et al. (2014), as well as in the period of exposure of the animals, we must consider the physiological and biochemical differences between the species of the rodents investigated. As discussed by Nogueira et al. (2003), metabolic differences observed in rats and mice, with the possibility of the formation of more toxic metabolites in mice, is important in explaining the differential effects observed in the species investigated.

It is known that tannery effluents have a very diverse and complex chemical composition, and may even vary between different tannery industries. Recently, Moysés (2010) identified more than 20 organic chemicals in effluent while analyzing the effects of in vitro exposure of tannery effluent on the activity of different enzymes in mice, rats and Drosophila melanogaster. The chemical variations of these residues and the complexity of compounds are related to different treatment methods used in the tannery industries, the manner in which the effluents are stored, as well as to the step of processing the bovine skin from which the effluents are produced. Therefore, the health effects of the ingestion of these effluents in organisms can be diverse and can vary between different species and strains, as mentioned above. Notwithstanding this, although detailed analysis of the organic composition of the effluents have not been conducted in this study, nor in the works of Kumar et al. (2008), Siqueira et al. (2011), Moysés et al. (2014), Silva et al. (2015), Lemos et al. (2015) e Ferreira et al. (2015), hampering our understanding of the mechanisms related to the anxiolytic effect observed in the animals, it is suggested that constituents (organic and/or inorganic) of the effluent may have acted in the animals' body similar to benzodiazepines, drugs commonly used to treat anxiety disorders (Andreatini et al., 2001).

As discussed by Kryger et al. (1985), this group of substances is characterized by neurotransmitter action in the gamma-amino butyric acid system (GABA) that is the major inhibitory neurotransmitter of the central nervous system. Besides alcohol, GABA and its agonists, such as benzodiazepines, barbiturates, and imidazopiridinos derivatives, act in a transmembrane structure of the GABA-receptor called the "GABAA complex" (Kandel et al., 2000). The GABAA complex, in turn, is mainly made-up of five protein subunits ( 2 alphas, 2 betas and one gamma) with extramembrane receptors for various substances (Kryger et al., 1985). These substances bind to receptors in the GABA complex and directly or indirectly open the chloride channel, causing an influx of anions into the neuron, which results in the in hyperpolarization of the cell, producing an anxiety-like effect (Andreatini et al., 2001). Although rare, some studies involving contaminants in rodents demonstrate behaviors similar to those seen in this study (Stangherlin et al. 2006; López-Crespo et al., 2007; Chen et al., 2011), supporting the hypothesis that the tannery effluent which was used may have acted 
similarly to these drugs.

In relation to the forced-swim test, which is a predictor test of depression in laboratory animals (Porsolt et al., 1977), it was observed that the animals in the $10 \%$ tannery effluent diluted with water group exhibited more time in climbing behavior and reduced immobility time (the first two minutes of the test and total test time - 6 minutes), as compared to the other experimental groups (Figure 5). Thus, these data show an antidepressant behavior of the animals exposed to higher effluent concentrations in the present study, which differs from Siqueira et al. (2011) and Moysés et al. (2014). In these studies, the authors suggest that exposure to tannery effluent for brief time periods does not induce depression or antidepressant behavior in Swiss mice and Wistar rats exposed to concentrations of $1 \%$ and $5 \%$ effluent, respectively. It is believed that these differences are also related to the particularities of the various studies, such as the sex of the evaluated animals, the exposure period, the effluent concentrations used and the chemical composition of the effluents.

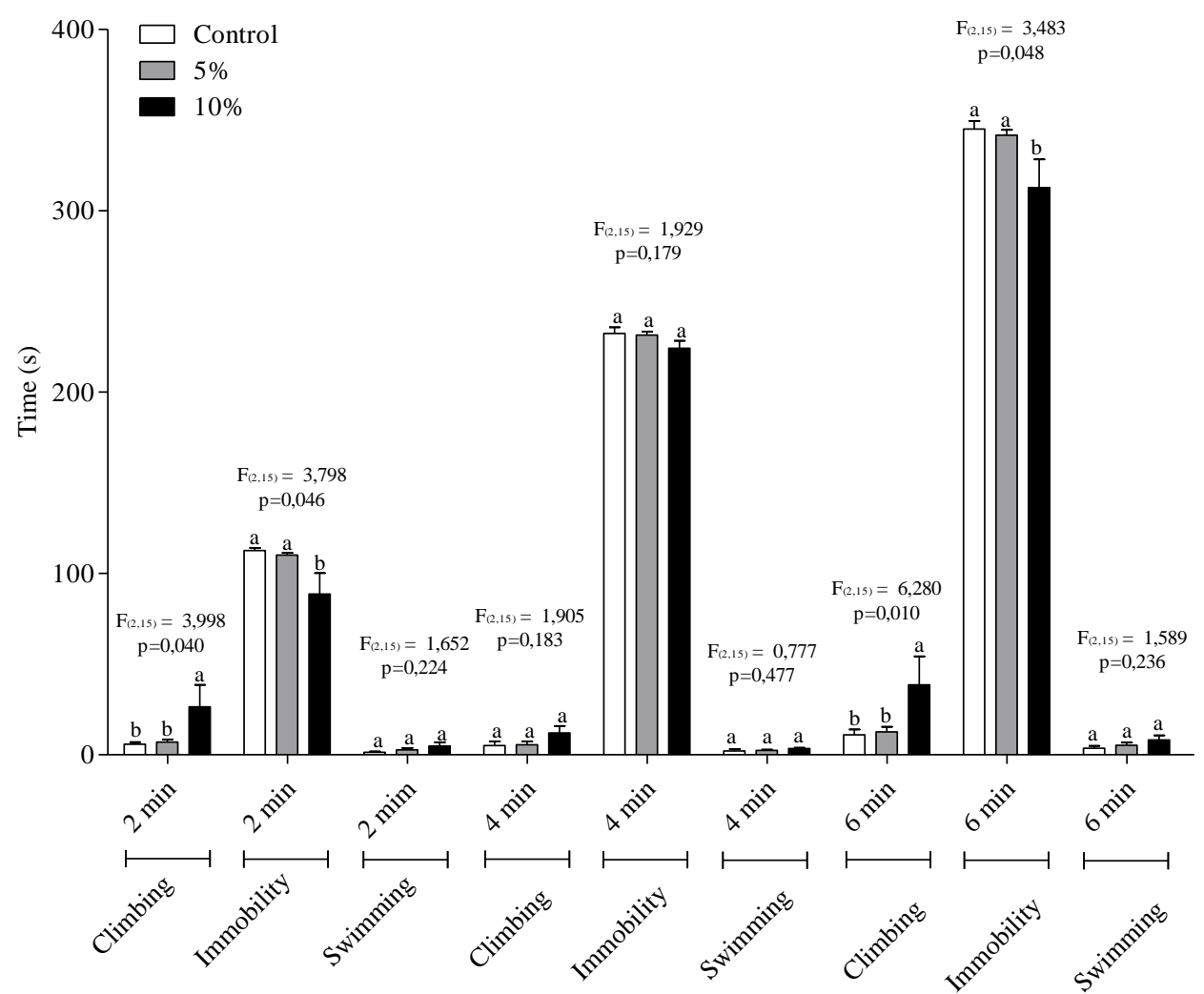

Figure 5. Climbing, immobility and swimming behavior time (at different times in the forced-swim test) exhibited by female Swiss mice (in the dioestrus phase) exposed or not to tannery effluent diluted with water. Different letters indicate significant differences among the experimental groups. All data were submitted to analysis of variance (one-way ANOVA) with Tukey's post-test at $5 \%$ probability. Control group $(n=6), 5 \%$ tannery effluent group $(n=6)$ and $10 \%$ tannery effluent group $(n=6)$. Different letters indicate significant differences among the experimental groups.

It is important to consider that tannery effluents have a very complex and diversified chemical constitution that can vary between different tanning industries (Shakir et al., 2012). Recently, Moysés (2010), when analyzing the effects of in vitro exposure to tannery effluent on the activity of different mice and rat enzymes and Drosophila melanogaster, identified more than 20 organic chemical compounds in the effluent. The chemical variation of these 
residues and the complexity of the compounds are related to different treatment methods used in the tanning industries, how these effluents are stored, as well as to the bovine hideprocessing stage from which the effluents are produced (Shakir et al., 2012). Thus, although Moysés (2010) has analyzed effluent, it is impossible to compare those results with other studies due to lack of information regarding the composition of the other effluents.

Nevertheless, it is suggested that the highest concentration of tannery effluent intake by the animals acted similarly to antidepressants also commonly used in the treatment of depression. Different studies have shown that rodents (mice or rats) in the forced-swim test, under the effect of different antidepressants, exhibit increased mobility and/or increased climbing, supporting the hypothesis that the tannery effluent used in the instant study (at the $10 \%$ concentration) may have acted in a similar way to antidepressants (Cryan et al., 2005; Can et al., 2012; Costa et al., 2013). Other studies have observed an antidepressant effect of different contaminants in rodents (Posser et al., 2008; Acker et al., 2009; Takasaki et al., 2013), which reinforces our hypothesis. However, new research is needed regarding the mechanisms related to the observed effects.

\section{CONCLUSION}

The exposure of female Swiss mice (in dioestrus phase) to tannery effluent concentrations of 5\% and $10 \%$ causes neurobehavioral changes consistent with anxiolytic and antidepressant effects, without causing physical changes in the animals. It is suggested that the mechanisms by which the tannery effluent interferes with the physiology and behavior of the animals be investigated in detail.

\section{REFERENCES}

AMERICAN PUBLIC HEALTH ASSOCIATION - APHA; AMERICAN WATER WORKS ASSOCIATION - AWWA; WATER ENVIRONMENT FEDERATION - WEF. Standard methods for the examination of water and wastewater. 21 th. Washington, 2005.

ACKER, C. I.; LUCHESE, C.; PRIGOL, M.; NOGUEIRA, C. W. Antidepressant-like effect of diphenyl diselenide on rats exposed to malathion: involvement of $\mathrm{Na}+\mathrm{K}+\mathrm{ATPase}$ activity. Neuroscience Letters, v. 455, n. 3, p. 168-172, 2009.

http://dx.doi.org/10.1016/j.neulet.2009.03.069

ANDREATINI, R.; BOERNGEN-LACERDA, R.; ZORZETTO FILHO, D. Pharmacological treatment of generalized anxiety disorder: future perspectives. Revista Brasileira de Psiquiatria, São Paulo, v. 23, n. 4, p. 233-242, 2001. http://dx.doi.org/10.1590/S151644462001000400011

ANSELONI, V. Z.; BRANDÃO, M. L. Ethopharmacological of behavior of rats using variations of the elevated plus-maze. Behavioural Pharmacology, v. 8, n. 6-7, p. 533540, 1997. http://dx.doi.org/10.1097/00008877-199711000-00011

BEHMER, A. O.; TOLOSA, E. M.; FREITAS-NETO, A. G. Manual de técnicas para histologia normal e patológica. São Paulo: Art/Edusp, 1976. 155 p.

BYERS, S. L.; WILES, M. V.; DUNN, S. L.; TAFT, R. A. Mouse estrous cycle identification tool and images. Plos ONE, v. 7, n. 4, p. e35538, 2012.

http://dx.doi.org/10.1371/journal.pone.0035538 
CAN, A.; DAO, D. T.; ARAD, M.; TERRILLION, C. E.; PIANTADOSI, S. C.; GOULD, T. D. The mouse forced swim test. Journal of Visualized Experiment, v. 59, p. 3638, 2012. http://dx.doi.org/10.3791/3638

CHANDRASEKARAN, V.; DILARA, K.; PADMAVATHI, R. Pulmonary functions in tannery workers - A cross-sectional study. Indian Journal of Physiology and Pharmacology, v. 58, n. 3, p. 206-210, 2014.

CHEN, W. Q.; YUAN, L.; XUE, R.; LI, Y. F.; SU, R. B.; ZHANG, Y. Z.; LI, J. Repeated exposure to chlorpyrifos alters the performance of adolescent male rats in animal models of depression and anxiety. Neurotoxicology, v. 32, n. 4, p. 355-361, 2011. http://dx.doi.org/10.1016/j.neuro.2011.03.008

COSTA, A. P. R. et al. A proposal for refining the forced swim test in Swiss mice. Progress in Neuro-Psychopharmacology \& Biological Psychiatry, v. 45, p. 150-155, 2013. http://dx.doi.org/10.1016/j.pnpbp.2013.05.002

CRYAN, J.; PAGE, M.; LUCKI, I. Differential behavioral effects of the antidepressants reboxetine, fluoxetine, and moclobemide in a modified forced swim test following chronic treatment. Psychopharmacology, v. 182, n. 3, p. 335-344, 2005. http://dx.doi.org/10.1007/s00213-005-0093-5

CUBEROS, E.; RODRIGUEZ, A. I.; PIETRO, E. Niveles de cromo y alteraciones de salud en una población expuesta a las actividades de curtiembres en Bogotá, Colombia. Revista de Salud Pública, v. 11, n. 2, p. 278-289, 2009. http://dx.doi.org/10.1590/S0124-00642009000200012

ESPEJO, E. F. Effects of weekly or daily exposure to the elevated plus-maze in male mice. Behavioural Brain Research, v. 87, n. 2, p. 233-238, 1997. http://dx.doi.org/10.1016/S0166-4328(97)02286-9

ESTRELA, D. C. et al. Predictive behaviors for anxiety and depression in female Wistar rats subjected to cafeteria diet and stress. Physiology \& Behavior, v. 151, p. 252-263, 2015. http://dx.doi.org/10.1016/j.physbeh.2015.07.016

FERREIRA, R. O. et al. Análise de toxicidade aguda e determinação da dose letal mediana $\left(\mathrm{DL}_{50}\right)$ de efluente de curtume em camundongos Swiss. Multi-Science Journal, v. 1, n. 3, p. 83-87, 2015.

GARAVELHO, L. P Administração de 8-OH-DPAT no septo dorso-lateral de camundongos não altera a ansiedade no teste do Labirinto em Cruz Elevado (LCE). 2005. 85f. Monografia (Bacharelado em Psicologia) - Universidade Federal de São Carlos, São Carlos, 2005.

GÖDECKE, M. V.; RODRIGUES, M. A. S.; NAIME, R. H. Resíduos de curtume: estudo das tendências de pesquisa. Revista Eletrônica em Gestão, Educação e Tecnologia Ambiental, v. 7, n. 7, p. 1357-1378, 2012. http://dx.doi.org/10.5902/223611705779

GOLDMAN, J. M.; MURR, A. S.; COOPER, R. L. The rodent estrous cycle: characterization of vaginal cytology and its utility in toxicological studies. Birth Defects Research, v. 80, n. 2, p. 84-97, 2007. http://dx.doi.org/10.1002/bdrb.20106 
GREENE, L. E.; RIEDERER, A. M.; MARCUS, M.; LKHASUREN, O. Associations of fertility and pregnancy outcomes with leather tannery work in Mongolia: a pilot study. International Journal of Occupational and Environmental Health, v. 16, n. 1, p. 6068, 2012. http://dx.doi.org/10.1179/107735210800546100

KANDEL, E. R.; SCHWARTZ, J. H.; JESSEL, T. M. Principles of Neural Science. New York: McGraw-Hill, 2000. 120 p.

KOMADA, M.; TAKAO, K.; MIYAKAWA, T. Elevated plus maze for mice. Journal of Visualized Experiments, v. 22, p. 1-3, 2008. http://dx.doi.org/10.3791/1088

KRYGER, H. M.; ROTH, T.; DEMENT, W. C. Principles and practice of sleep medicine. 3th. Philadelphia: Saunders, 1985.

KUMAR, V.; MAJUMDAR, C.; ROY, P. Effects of endocrine disrupting chemicals from leather industry effluents on male reproductive system. The Journal of Steroid Biochemistry and Molecular Biology, v. 111, n. 3-5, p. 208-216, 2008. http://dx.doi.org/10.1016/j.jsbmb.2008.06.005

LEMOS, D. C. S. et al. Toxicidade aguda em camundongos BALB/c expostos à efluentes de curtume. Multi-Science Journal, v. 1, n. 3, p. 56-63, 2015.

LÓPEZ-CRESPO, G. A.; CARVAJAL, F.; FLORES, P.; SÁNCHEZ-SANTED, F.; SÁNCHEZ-AMATE, M. C. Time course of biochemical and behavioral effects of a single high dose of chlorpyrifos. Neurotoxicology, v. 28, n. 3, p. 541-547, 2007.

LUNA, A.; MEISTER, H. P.; SZANTO, P. B. Esophageal varices in the absence of cirrhosis; Incidence and characteristics in congestive heart failure and neoplasm of the liver. American Journal of Clinical Pathology, v. 49, n. 5, p. 710-717, 1968.

MATSUMOTO, S. T.; et al. Genotoxicity and mutagenicity of water contaminated with tannery effluents, as evaluated by micronucleus test and comet assay using the fish Oreochomis niloticus and chromosome aberrations in onion root-tips. Genetics and Molecular Biology, v. 29, n. 1, p. 148-158, 2006. http://dx.doi.org/10.1590/S141547572006000100028

MITTEREGGER JR., H.; SILVA, J. DA. ARENZONC, A.; PORTELAC, C. S.; FERREIRA, I. C. F. DE S.; HENRIQUES, J. A. P. Evaluation of genotoxicity and toxicity of water and sediment samples from a Brazilian stream influenced by tannery industries. Chemosphere, v. 67, n. 6, p. 1211-1217, 2007. http://dx.doi.org/10.1016/j.chemosphere.2006.10.048

MOYSÉS, F. S. et al. Exposition to tannery wastewater did not alter behavioral and biochemical parameters in Wistar rats. Physiology \& Behavior, v. 129, p. 160-166, 2014. http://dx.doi.org/10.1016/j.physbeh.2014.02.022

MOYSÉS, F. S. Rato como modelo animal para avaliação da toxicidade induzida pela exposição crônica a efluentes de curtumes: parâmetros comportamentais e bioquímicos. 2010. 56f. Dissertação (Mestrado em Ciências Biológicas) - Instituto de Ciências Básicas da Saúde, Universidade Federal do Rio Grande do Sul, Porto Alegre, 2010.

NOGUEIRA, C. W.; MEOTTI, F. C.; CURTE, E.; PILISSAO, C.; ZENI, G.; ROCHA, J. B. T. Investigations into the potential neurotoxicity induced by diselenides in mice and rats. Toxicology, v. 183, n. 1, p. 29-37, 2003. 
ORAL, R.; MERIÇA, S.; TÜNAY, O.; NICOLA, E.; PETRUZZELLI, D.; PAGANO, G. Multi-species toxicity monitoring in a chromium-based leather tannery wastewater. In: INTERNATIONAL CONFERENCE ON ENVIRONMENTAL SCIENCE AND TECHNOLOGY, 9., 2005, Rhodes Island. Disponível em: http://www.srcosmos.gr/ srcosmos/showpub.aspx?aa=6537. Acesso em: 15 nov. 2015.

PIETROPAOLO, S.; FELDON, J.; YEE, B. K. Environmental enrichment eliminates the anxiety phenotypes in a triple transgenic mouse model of Alzheimer's disease. Cognitive, Affective, \& Behavioral Neuroscience, v. 14, n. 3, p. 996-1008. 2014. http://dx.doi.org/10.3758/s13415-014-0253-3

PIRES JÚNIOR, H.; BORGES, L.; SOUSA, L.; CUNHA, L.; LINO JÚNIOR, R.; MELO, D. et al. Avaliação da toxicidade aguda do extrato hexânico de frutos de Melia azedarach (Meliaceae) em camundongos. Ciência Animal Brasileira, v. 13, n. 4, p. 512-519, 2012. http://dx.doi.org/10.5216/cab.v13i4.15179

PORSOLT, R. D.; LEPICHON, M.; JALFRE, M. Depression: a new animal model sensitive to antidepressant treatments. Nature, v. 266, n. 5604, p. 730-732, 1977. http://dx.doi.org/10.1038/266730a0

POSSER, T.; KASTER, M. P.; BARAÚNA, S. C.; ROCHA, J. B.; RODRIGUES, A. L.; LEAL, R. B. Antidepressant-like effect of the organoselenium compound ebselen in mice: evidence for the involvement of the monoaminergic system. European Journal of Pharmacology, v. 602, n. 1, p. 85-91, 2008.

http://dx.dio.org/10.1016/j.ejphar.2008.10.055

PRABAKARAN, M.; BINURAMESH, C.; STEINHAGEN, D.; DINAKARAN MICHAEL, R. Immune response in the tilapia, Oreochromis mossambicus on exposure to tannery effluent. Ecotoxicology and Environmental Safety, v. 68, n. 3, p. 372-378, 2007. http://dx.doi.org/10.1016/j.ecoenv.2006.11.016

RABELO, L. M.; SILVA, B. C.; DE ALMEIDA, S. F.; DA SILVA, W. A.; MENDES, B. O.; GUIMARÃES, A. T. B. et al. Memory deficit in Swiss mice exposed to tannery effluent. Neurotoxicology and Teratology, v. 55, n. 1, p. 45-49, 2016. http://dx.doi.org/10.1016/j.ntt.2016.03.007

REIMER, A. E. et al. Rats with differential self-grooming expression in the elevated plusmaze do not differ in anxiety-related behaviors. Behavioural Brain Research, v. 292, p. 370-380, 2015. http://dx.doi.org/10.1016/j.bbr.2015.06.036

RUMIN, C. R.; SILVA, D. B.; SOUZA, M. A. R. Intervenção em Saúde do trabalhador em um curtume do Oeste Paulista. Revista Psicologia: Organizações e Trabalho, v. 13, n. 2, p. 127-140, 2013.

SHAKIR, L.; EJAZ, S.; ASHRAF, M.; QURESHI, N. A.; ANJUM, A. A.; ILTAF, I. et al.Ecotoxicological risks associated with tannery effluent wastewater. Environmental Toxicology and Pharmacology, v. 34, n. 2, p. 180-191, 2012.

SILVA, B. C. et al. Determinação de doses letais de efluente de curtume em camundongos C57B1/6J. Multi-Science Journal, v. 1, n. 2, p. 45-49, 2015. 
SIQUEIRA, I. R.; VANZELLA, C.; BIANCHETTI, P.; RODRIGUES, M. A. S.; STÜLP, S. Anxiety-like behaviour in mice exposed to tannery wastewater: the effect of photoelectrooxidation treatment. Neurotoxicology and Teratology, v. 33, n. 4, p. 481484, 2011. http://dx.doi.org/10.1016/j.ntt.2011.05.008

SOUZA, J. M.; GUIMARÃES, A. T. B.; SILVA, W. A. M.; MENDES, B. O.; ESTRELA, D. C.; RODRIGUES, A. S. L. et al. Histopathological assessment of C57B1/6J mice organs exposed to tannery effluents. Revista Ambiente \& Água, v. 11, n. 1, p. 24-34, 2016. http://dx.doi.org/10.4136/ambi-agua.1694

STANGHERLIN, E. C.; FAVERO, A. M.; WEIS, S. N.; ZENI, G.; ROCHA, J. B.; NOGUEIRA, C. W. Assessment of reproductive toxicity in male rats following acute and sub-chronic exposures to diphenyl diselenide and diphenyl ditelluride. Food and Chemical Toxicology, v. 44, n. 5, p. 662-669, 2006.

http://dx.doi.org/10.1016/j.fct.2005.09.006

TAGLIARI, K. C.; CECCHINI, R.; ROCHA, J. A. V.; VARGAS, V. M. F. Mutagenicity of sediment and biomarkers of oxidative stressin fish from aquatic environments under the influence of tanneries. Mutation Research/Genetic Toxicology and Environmental Mutagenesis, v. 561, n. 1-2, p. 101-117, 2004.

http://dx.doi.org/10.1016/j.mrgentox.2004.04.001

TAJU, G. et al. Comparison of in vitro and in vivo acute toxicity assays in Etroplus suratensis (Bloch, 1790) and its three cell lines in relation to tannery effluent. Chemosphere, v. 87, n. 1, p. 55-61, 2012. http://dx.doi.org/10.1016/j.chemosphere.2011.11.056

TAKASAKI, I.; OOSE, K.; OTAKI, Y.; IHARA, D.; FUKUCHI, M.; TABUCHI, A. et al. Type II pyrethroid deltamethrin produces antidepressant-like effects in mice. Behavioural Brain Research, v. 257, p. 182-188, 2013.

http://dx.doi.org/10.1016/j.bbr.2013.09.044

TIGINI, V.; GIANSANTI, P.; MANGIAVILLANO, A.; PANNOCCHIA, A.; VARESE, G. Evaluation of toxicity, genotoxicity and environmental risk of simulated textile and tannery wastewaters with a battery of biotests. Ecotoxicology and Environmental Safety, v. 74, n. 4, p. 866-873, 2011. http://dx.doi.org/10.1016/j.ecoenv.2010.12.001

WALF, A. A.; FRYE, C. A. The use of the elevated plus maze as an assay of anxiety-related behavior in rodents. Nature Protocols, v. 2, n. 20, p. 322-8, 2007. http://dx.doi.org/10.1038/nprot.2007.44

WAXMAN, D. J.; HOLLOWAY, M. G. Sex differences in the expression of hepatic drug metabolizing enzymes. Molecular Pharmacology, v. 76, n. 2, p. 215-228, 2009. http://dx.doi.org/10.1124/mol.109.056705 